\title{
The Attitude of Non-Education Lecturers to Education Students: Implication for Students' Academic Performance
}

\author{
Felicia I. Ofoegbu and Jennifer J. Agbaire \\ Department of Educational Studies and Management, Faculty of Education, University of Benin, Benin city
}

\begin{abstract}
Trainee teachers in Nigerian universities are generally required to undergo training not only in the theories, principles and practice of education but also in the content of their subject areas. Training in the latter often covers a large part of the entire programme and is usually offered by 'servicing' faculties such as Arts/Humanities, Sciences and Social Sciences depending on students' area of specialization. The academic performance of university trainee teachers especially in courses received from servicing faculties has been observed to be poor, and the attitude of lecturers in servicing faculties has been cited as a major contributing factor. This paper is a study of the attitude of non-education lecturers to Faculty of Education students in the University of Benin, Nigeria, and the effects on the students' academic performance. An Instrument titled Lecturers' Attitude and the Effects on Students Questionnaire (LAESQ) was administered to a sample of two hundred (200) students. Findings from the study indicate that: the attitude of non-education lecturers to education students is negative and biased; the lecturers' attitude is not significantly difference between the lecturers in the servicing faculties and lecturers' gender; students' academic performance is adversely and significantly affected by the lecturers' attitude. Several recommendations were made based on the findings.
\end{abstract}

Keywords: Attitude, Non-Education Lecturers, , Students' Performance, Trainee Teachers

\section{Introduction}

The concept of education as the foundation of individual and national advancement has been expounded by several authors (Akinbote, 2007; Saint, Hartnett \& Strassner, 2003; Nwagwu, 1976; Fafunwa, 1968). The African continent in general and Nigeria in particular, have come to view education as the key to constructive social change in the direction of cultural dynamism, economic progress, political stability and technological advancement. Hence it has been adopted as an instrument per excellence for human empowerment and national development (FRN, 2004).

Since the attainment of political independence, Nigeria has strived to improve her educational system with a view to making it effective enough to achieve laid down national goals and objectives. In this regard however, many have widely acknowledged that no educational system can rise above the quality of its personnel, particularly its teachers. In fact, to Fafunwa (1967) and Afe (1995), the education of the teacher should be regarded as the bedrock for national development. This in the first place, justifies why Education exists as a discipline in Nigerian tertiary institutions.

Many lecturers and students of education believe that the prejudice for education students by lecturers in the 'servicing' departments is real and militates against the students' good performance in the subject areas concerned. This should be a matter of considerable interest that would need in-depth analysis to confirm this impression which has been created over time whereby education students are generally considered as material inferior to their counterparts directly admitted to the departments concerned. In the light of the foregoing, the study attempts to find out whether the attitude of non-education lecturers has any effect on the academic performance of education students.

For several centuries, formal education has been carried out by individuals who acted as teachers. Hence Aregbeyen (2010) states that the role of teachers in the transmission of knowledge and skills is generally accepted and recognized. Consequently, Faculties, Institutes and Colleges of Education across the country have the onus of equipping students (potential teachers) with the theoretical knowledge, practical experience and other competences necessary to make them qualified teachers, educational managers and guidance counselors with a view to producing such calibre of personnel who are capable of improving the educational system. If indeed education is the instrument for all-round development and the teacher is the pivot of the educational system, it doubtlessly follows that the task of a teacher or any educational personnel is an enormous one. There is no gainsaying the fact therefore that training to be one is definitely not a "walk in the park". Nevertheless, it has been observed that Education as a discipline and the students of Education are often not at the receiving end of positive reactions, perceptions and attitude. This can be traced to several factors ranging from the state of low esteem of the teaching profession in Nigeria to the low demand and regard for Education courses in comparison with courses in other faculties mainly due to ignorance or naivety on the part of the stakeholders. 
The opinion that Nigerian teachers' status, remuneration, welfare and general conditions of service are not commensurate with their work and those of their counterparts in other professions has been repeatedly expressed. In the words of Fakoya (2009:7)

'Its (teaching's) social and cultural functions have never been critically challenged, but nevertheless the public has not adequately supported teaching. Compared to other learned professions - such as medicine, law, engineering, and architecture - teaching ranks rather low. Some teachers are dissatisfied with, and even depressed about their professional standing. They feel that the work load is too heavy, and the recognition and appreciation are too limited. They think that they do not have sufficient opportunities to advance in their careers and that they have no power to control the content and form of their work'.

Furthermore, Akinbote (2000) is of the opinion that the lowering of the admission requirements for Education programmes in order to attract more students, has adversely affected the image and prestige of the teaching profession. This is similar to Liberman's (1956) view that the quality of the entry qualifications of recruits into a profession is bound to affect not only their efficiency and effectiveness but also the prestige of the profession.

Consequently, teaching has been regarded with contempt and relegated to the background as many aspiring young people do not want to be stuck with such a demanding profession in which ready cash and vast immediate reward cannot even be contemplated. According to the findings from a study of student teachers' attitude to teaching conducted by Adeleke (1999), $87 \%$ of undergraduate student teachers in the Faculty of Education in one of the most prominent universities in Nigeria would not like to teach at the primary school level. More so, $88 \%$ of the remaining paltry $13 \%$ who would like to teach at all would not like to remain in teaching for a long time. It is no wonder therefore that Akinbote (2007) asserts that in Nigeria there is probably no other profession that has been scorned more than teaching.

Not unconnected with this is the fact that the enrolment figures of applicants who originally opt to study Education is continually on the decline since their career aspirations are often set on such disciplines as Law, Engineering, Medicine, Mass-communication, Banking and Accountancy. Unfortunately, it is not so much because they understand what studying these courses entail in the short and long run but because these are the so-called 'prestigious' and 'popularly acclaimed' courses of study. Fakoya (2009) succinctly explains that there exists in Nigeria, this general notion of teaching as a second-choice profession. The result is that Education faculty becomes the dumping ground for unwilling, and uninterested students who could not make it into their original choice of discipline. While it is true that some eventually grow to love the discipline, it is also true that most of this calibre of students are often ashamed of their course of study and are often distracted from academic concentration as they fruitlessly search for ways to transfer to other faculties even up to their third year when most of them realize that their effort to transfer has ultimately ended in futility.

Apart from distraction and lack of interest there appear to be several causes of poor academic performance among education students. The perceptions and corresponding attitude of lecturers in the servicing faculties towards these students have been identified as a major cause of the poor academic performance in many cases. A good number of concerned Educators (Akinbote, 2007; Afe, 2006) at various times have lamented that poor academic performance among students in the Faculties of Education in many Nigerian universities is relatively high. Although many factors have been enumerated as being responsible for this phenomenon, the perception of non-education lecturers in the servicing faculties which influences their attitude towards the students is a source of concern. It is quite disappointing to note that for some unprofessional and lame reasons, many lecturers from servicing faculties tend to consider Education students inferior to their own students and treat them as such.

Lecturers who are supposed to be academics and who should therefore know better do not often see Education students as equivalents to students in their own faculty. This is usually reflected not only in their actions but also in clear-cut statements of their opinion about the students. Thus such lecturers are known to strive to be excluded from teaching the 'Education class' when students are grouped and shared among lecturers. They tend to evade lectures totally or attend very irregularly, teach with obvious disinterest, mark scripts with stereotyped and presumptuous misconceptions and generally handle Education students with some bias and a general air of lassiez-faire as a result of the negative perception they have of the students involved. Such Education students' already belittled ego is further crushed and their initial lack of interest, intensified by such perception and actions, and the result is generally poor performance.

The study is hinged on Ajzen's (1991) theory of planned behaviour, an extension of the theory of reasoned action. The theory is apt for the study since it has been used in research to determine behaviour arising from attitudes. Attitude in this study is a dispositional behavior expressed in achieving specific and defined results so that the organization can achieve its goals and objectives (Rudman 1998). It is one's disposition to work. Literature has provided considerable support for effective attitudes that promote positive outcomes (Gourneau, 2005 and Larson and Silverman 2000). According to Lain (2006) the right attitude can change 
people's thoughts and behavior. Therefore effective attitudes employed by teachers ultimately can make a positive difference on the live of their students.

It has already been stated that a good percentage of undergraduates in Education faculties did not find themselves there by choice - hence they struggle to fit in, adapt and love what they have to study. It is largely the responsibility of the lecturer not just to teach the students what they should know but also to help them adapt to their educational circumstances in the best possible way. However, many lecturers in such servicing faculties as the Sciences, Social Sciences and Arts do not seem to partner with Education lecturers to make this happen for the average Education student. This perceived prejudice by lecturers who students naturally view as mentors, negatively affects the students in more ways than one, all of which culminate in poor academic performance and this is the thrust of this study.

\subsection{Research Questions}

1. What is the attitude of non-education lecturers to education students?

2. Does the attitude of non-education lecturers affect the academic performance of non-education students?

\subsection{Hypotheses}

The following hypotheses were formulated to guide the study;

1. There is no significant difference between servicing department lecturers in their attitude toward education students.

2. There is no significant gender difference in the attitude of non-education lecturers to education students.

3. The attitude of non-education lecturers does not significantly affect the academic performance of education students.

\section{Sample/Sampling Technique}

The population of the study comprises all 400 level education students in the 2011/2012 academic session. The choice of 400 (final) level students was prompted by the fact that they had witnessed and experienced the varied behavioural responses of non-education lecturers and had perhaps been able to rise to the challenges of the attitudes by adjusting their learning styles.

Proportional purposive random sampling technique was used to select students from the five departments that make up the Faculty of Education in the University of Benin. The departments are Adult and Non-Formal Education (40), Educational Studies and Management (50), Educational Psychology and Curriculum Studies (50), Health, Environmental and Human Kinetics (30) and Vocational and Technical Education (30). Students were selected from each department in proportion relative to the number in the class for the cohort session. Altogether, a total of 200 students were used for the study.

The study was a survey and so a questionnaire titled Research Questionnaire on Lecturers' Attitude and the Effects on Students (RQLAES) was used as instrument for collecting data. It contained sixteen (16) items with 1 to 9 focusing on the attitude of non-education lecturers and 10 to 16 on the effect of such attitudes on the academic performance of education students. The instrument was structured according to the 4-point Likert type. Cronbach's Alpha was used to establish a reliability test of 0.72 .

\section{Data Analysis/Findings}

Research Question 1: What is the attitude of non-education lecturers to education students? Table 1: Non-Education Lecturers' Attitude to Education Students

\begin{tabular}{|c|c|c|c|c|}
\hline $\mathbf{S} / \mathbf{N}$ & Items & Mean & $\begin{array}{l}\text { Standard } \\
\text { Deviation }\end{array}$ & Remark \\
\hline 1. & Negative attitude. & 3.38 & 606 & Agreed \\
\hline 3. & More positive attitude from female non-education lecturers & 1.60 & .549 & Disagreed \\
\hline 4. & More positive attitude from male non-education lecturers & 1.57 & .526 & Disagreed \\
\hline 5. & $\begin{array}{l}\text { Lack of interest in the academic development of education } \\
\text { students. }\end{array}$ & 3.12 & .708 & Agreed \\
\hline 6. & More interest in the academic development of their own students. & 3.18 & .640 & Agreed \\
\hline 7. & Low commitment to teaching education students & 3.36 . & .717 & Agreed \\
\hline 8. & $\begin{array}{l}\text { Less punctuality and regularity to lectures involving only } \\
\text { education students }\end{array}$ & 2.97 & .657 & Agreed \\
\hline 9. & More regularity to lectures involving their own students & 3.06 & .706 & Agreed \\
\hline
\end{tabular}

The analysis on Table 1 shows that all the items except the second and third, have mean scores (3.38, $3.17,3.12,3.18,3.36,2.97$ and 3.06 respectively) which are above the criterion mean of 2.50 . The indication 
here is that the respondents agreed with the seven items in question. The mean scores (1.60 and 1.57) of the second and third items are respectively below the criterion mean indicating that the respondents disagreed with both items. The Standard Deviation figures which are all below 1.96 indicate that the respondents did not greatly vary in their responses but were rather in strong agreement with one another. This result reveals that the attitude of non-education lecturers to education students is negative and generally bordering on bias and rejection.

It also reveals that this attitude is often portrayed in the lecturers' lack of interest in the academic development of education students; low commitment to teaching education students as well as less punctuality and regularity to lectures involving only education students. As revealed by the result, these characteristic attitudes contrast with the treatment the lecturers give their own students; they show more interest in their students' academic well-being and are often more regular and punctual to lectures involving their own students. According to the result, the attitude of both the female and male lecturers are comparatively the same as the students do not receive a more positive attitude from either group in comparison to the other.

Research Question 2: Does the attitude of non-education lecturers affect the academic performance of noneducation students?

Table 2: Effect of Non-Education Lecturers' Attitude on Education Students' Academic Performance

\begin{tabular}{|c|c|c|c|c|}
\hline $\mathbf{S} / \mathbf{N}$ & Items & Mean & $\begin{array}{l}\text { Standard } \\
\text { Deviation }\end{array}$ & Remark \\
\hline 1. & Difficulty in adjusting to academics & 2.99 & .521 & Agreed \\
\hline 2. & Poor adaptation to academic life and other university intricacies & 3.02 & .459 & Agreed \\
\hline 3. & Lack of interest in studies & 3.36 & .710 & Agreed \\
\hline 4. & Limit on amount of course content covered in lectures & 3.07 & 669 & Agreed \\
\hline 5. & Poor performance in non-education courses & 3.02 & .698 & Agreed \\
\hline 6. & Adverse effects on overall academic performance. & 3.14 & .518 & Agreed \\
\hline 7. & Better academic performance in the face of positive attitude & 3.37 . & .561 & Agreed \\
\hline
\end{tabular}

Table 2 above reveals that the mean scores for all the items answering the second research question are $2.99,3.02,3.36,3.07,3.02,3.14$ and 3.37 respectively. The mean scores are all above the criterion mean of 2.50 and the Standard deviations $(.521, .459, .710, .669, .698, .518$ and .561$)$ are all below 1.96 . This implies that the respondents were closely in agreement that the lecturers' attitude affects the academic performance of the students one way or the other. The result specifically points to the revelation that non-education lecturers' attitude is often responsible for education students' difficulty in adjusting to academics, poor adaptation to academic life, lack of interest in studies, limited amount of course content covered in lectures and poor performance in non-education courses and other intricacies of the university. The respondents generally agreed that the attitude of these lecturers have adverse effects on the overall academic performance of education students and that most education students would excel or do better in their academics in the face of a positive attitude from lecturers in servicing faculties and departments.

\subsection{Test of Hypotheses}

Ho 1: There is no significant difference between servicing department lecturers in their attitude toward education students

Table 3: Analysis of Variance (ANOVA) on Non-Education Lecturers' Attitude to Education Students on the Basis of Servicing Faculty

\begin{tabular}{lllllll}
\hline $\begin{array}{l}\text { Sources of } \\
\text { Variation }\end{array}$ & SS & Df & MS & F & P & Decision \\
\hline $\begin{array}{l}\text { Between } \\
\text { Groups }\end{array}$ & .454 & 2 & .227 & .131 & .878 & Not Sig. \\
Within & 342.266 & 197 & 1.737 & & & \\
$\begin{array}{l}\text { Groups } \\
\text { Total }\end{array}$ & 342.720 & 199 & & & & \\
\hline
\end{tabular}

Table 3 shows that the $\mathrm{F}$-value of .131 with $\mathrm{df}=2,197$ is not significant at $\mathrm{P}=.878>.05$. The null hypothesis of no significant difference is therefore retained. This means that from the responses of the various categories of sampled students, the attitude of non-education lecturers to education students is not significantly different on the basis of servicing faculty.

Ho 2: There is no significant gender difference in the attitude of non-education lecturers to education students. 
Table 4: t-test Analysis on Non-Education Lecturers' Attitude to Education Students' on the Basis of

\begin{tabular}{llllllll} 
& \multicolumn{7}{c}{ Lecturers' Gender } \\
\hline Variables & N & Mean & SD & Df & T & P & Decision \\
\hline $\begin{array}{l}\text { Female } \\
\text { Lecturers' }\end{array}$ & 200 & 1.60 & .549 & 199 & 1.094 & .275 & Sig. \\
$\begin{array}{l}\text { Attitude } \\
\text { Male }\end{array}$ & & & & & & & \\
$\begin{array}{l}\text { Lecturers } \\
\text { Attitude }\end{array}$ & 200 & 1.56 & .526 & & & & \\
\hline
\end{tabular}

With reference to Table 4 above, the Means and Standard Deviations of the respondents concerning the attitudes of female and male non-education lecturers towards education students are 1.60 and 1.56, and .549 and .526 respectively. The table shows that the $\mathrm{t}$-value of 1.094 at $\mathrm{df}=199$ is not significant at $\mathrm{P}=.275$. The null hypothesis is therefore retained since $\mathrm{P}$ is greater than .05 level of significance, meaning that female and male non-education lecturers do not significantly differ in their attitude towards education students.

Ho 3: The attitude of non-education lecturers does not significantly affect the academic performance of education students.

Table 5: Chi-square Analysis on the Effect of Non-Education Lecturers' Attitude on Education Students' Academic Performance

\begin{tabular}{llllc}
\hline Variables & df & $\boldsymbol{X}^{2}$ & P & Decision \\
\hline Poor performance in non-education courses. & 3 & 1.397 & .000 & Sig. \\
Adverse effects on overall academic performance. & 3 & 1.115 & .000 & Sig. \\
Better academic performance in the face of positive attitude. & 3 & 2.777 & .000 & Sig. \\
\hline
\end{tabular}

As revealed in Table 5, the $X^{2}-$ values for the three variables listed are significant at $\mathrm{P}=.000<.05$ hence the null hypothesis of no significant difference is rejected. This indicates that the attitude of noneducation lecturers significantly affects the academic performance of education students.

\section{Discussion}

One of the pertinent questions that the study posed was; does the attitude of non-education lecturers affect the academic performance of education students in Nigerian universities? Based on the perception of students, the findings revealed that the attitude of non-education lecturers, irrespective of sex or servicing faculty, significantly affected the academic performance of education students because the attitude of such lecturers to the undergraduate potential teachers is negative, biased and unprogressive (Akinbote, 2007). The result supports the assumption that education students are often on the receiving end of negative perception and intolerant attitude from non-education lecturers. The finding brings serious indictment on non-education lecturers that conduct and process teaching subjects.

In many countries including Nigeria, Educators are not held in high regard, an impression supported by the study and findings of Johnson and Birkland (2002). The negative thinking of non-education lecturers remains the dominant ideology that shapes education students' explanation for their level of academic performance. Hence taking time to reflect on the purpose of teacher education programmes, leads to the realization that the unsupportive attitude of non-education lecturers may be detrimental to teacher development.

\section{Implications and Conclusion}

The outcome of the study no doubt holds significant implications for teacher preparation and development programmes in view of the need for a fundamental change in the attitude of non-education lecturers. University Teacher Education and Development programmes are aimed at grooming quality teachers who can effectively handle the task of realizing the goals of the nation's educational system. Thus trainee teachers are the prospective bedrock for national development. In order to function efficiently in this capacity, the students are required to acquire certain skills and competences backed with sound and respected academic qualifications. Such would require that these students be exposed to good role models who would not only transmit effectively to them the requisite knowledge and skills but also portray an overall encouraging attitude that would motivate them in their professional career. Anything short of this in effect will mean producing halfbaked and mediocre teachers who are more or less worthless and therefore hurtful to the nation's school system.

It is concluded that the bias sometimes with disdain suffered by Education students, more often than not, is played down or made to border on make belief; they are treated and given a status rated as inferior to that of their colleagues who offer the same subjects but without the option of teaching. The findings of the study highlight the factuality of the situation by using firsthand experience of Education students and information obtained on the attitude of the non-education lecturers in whose hands the students apparently suffer the 
denigration. A situation, which hitherto, was denied or at best regarded as conjecture is affirmed by the findings of the study.

\section{Recommendations}

Based on the findings, it is recommended that:

1. Non-education lecturers must according to Shields (2006), ensure that the assumptions they make about teacher trainees do not result in tracking/stereotyping students into classes that are less challenging and in which expectations for their performance are lowered.

2. The role and attitude of non-education lecturers as designated lecturers in teacher development need to be 'rethought and redefined'. The lecturers must be made to realize that lack of opportunity to learn is not equated with lack of ability to learn and that once potential teachers are admitted into the university, they should be regarded as equal in status to their counterparts in other faculties.

3. Student-teachers, particularly fresh intakes, should be given proper career counseling orientation on topics such as the importance of the teacher, the negative perceptions and attitude they may receive due to ignorance of the culpable, and several practical strategies in order to ignore and surmount such negativity and succeed academically.

4. Appropriate authorities should engage in a periodic monitoring exercise on lecturers' teaching habits and outcomes (punctuality and regularity to class, completion of course outline and content, average student performance) preferably through the Students' Assessment of Lecturers system.

5. The Nigerian Government should make necessary provisions to implement the policy of ensuring that a professional degree in Education (e.g Postgraduate Diploma in Education) is a prerequisite for becoming a practicing teacher at any level of the educational system including the tertiary institutions.

6. The Government should also initiate measures to upgrade the status of the teacher and the teaching profession through improved salaries and other incentives accompanied by the upgrading of entrance requirements into teacher education programmes in order to make them more competitive.

\section{References}

[1]. Adeleke, T. O. Student Teachers' Perception and Attitude towards Teaching in the Primary School. B. Ed. Project Submitted to the University of Ibadan, Ibadan, Nigeria. (1999).

[2]. Afe, J. O. Reflections on becoming a Teacher and the Challenges of Teacher Education. University of Benin Inaugural Lecture Series No. 64.(2006)

[3]. Afe, J.O. Strategies for Educating Migrant Fishermen and their Families. The Nigerian Teacher Today (TNTT) A Journal of Teacher Education, 4. (1995), $66-72$.

[4]. Ajzen, I.) The Theory of Planned Behaviour. Organizational Behaviour and Human Decision Processes, 50 (2), (1991), $179-211$.

[5]. Akinbote, O. Problems of Poor Quality in Primary School Teacher Preparation: A Study of Nigeria's College of Education. African Journal of Educational Planning andPolicy Studies 1 (1) (2000), 33-39.

[6]. Akinbote , O. Problems for Teacher Education for Primary Schools in Nigeria: Beyond Curriculum Design and Implementation. Essays in Education Volume (22), (2007).

[7]. Aregbeyen, O. Students' Perception of effective Teaching and Effective Lecturer Characteristics at the University of Ibadan, Nigeria. Pakistan Journal of Social Sciences, 7 (2) (2010), 62-69.

[8]. Fafunwa, A.B. New Perspectives in African Education. Lagos: Macmillan and Company Ltd. (1967).

[9]. Fafunwa, A.B. Over a Hundred Years of Higher Education for Nigerians. Lagos: Federal Ministry of Information. (1968).

[10]. Fakoya, F.O. Report on Teaching Profession and Factors Inhibiting the Teaching Profession in Nigeria. An Unpublished Thesis Submitted to the Faculty of Education, University of Ibadan, Nigeria (2009).

[11]. Federal Republic of Nigeria National Policy on Education (4 ${ }^{\text {th }}$ ed.). Lagos: NERDC Press (2004).

[12]. Guourneau B. Five Attitudes of Effective Teachers: Implications for Teacher Training. www.usca.edu/essaysvoliz 2005/gourneau.pdf. (2005)

[13]. Johnson, S. \& Birkland, S.E, Pursuing a 'Sense of Success': New Teachers Explain their Career Decision. A Paper Presented at the Annual Meeting of the American Educational Research Association, New Orleans, L.A. Retrieved from http://www.gse.harvard.edu/-ngt/papers.html (2002).

[14]. Lain) A Teachers impact on students through language and attitude. Yahoo contributor network (2006

[15]. Larson, A. A. \& Silverman S A Description of caring behaviors of four physical education teachers. Paper presented at the annual meeting of the American Educational Research Association, New Orleans. (2000).

[16]. Liberman, M. Education as a Profession New Jersey: Prentice Hall. (1956)

[17]. Nwagwu, N. A UPE: Issues, Prospects and Problems. Benin City: Ethiope Publishing Corps (1976).

[18]. Saint, W., Hartnett, T.A. \& Strassner, E. Higher Education in Nigeria: A Status Report. Higher Education Policy (16), (2003), 259281

[19]. Shields, C. M. Creating Spaces for Value-Based Conversations; The Role of School Leaders in the $21^{\text {st }}$ Century. International Studies in Educational Administration: Journal of the Commonwealth Council for Educational Administration and Management, 34 (2), (2006), 62-81. 